\title{
The contribution of self efficacy to work engagement in nurses in makassar
}

\author{
Fatwal Islamiah \\ Department of Psychology \\ Hasanuddin University \\ Makassar, Indonesia \\ Fislamiah@gmail.com
}

\author{
Muhammad Tamar \\ Department of Psychology \\ Hasanuddin University \\ Makassar, Indonesia
}

\author{
Hillman Wirawan \\ Department of Psychology \\ Hasanuddin University \\ Makassar, Indonesia
}

\begin{abstract}
This research aims to find out how far self-efficacy influences work engagement in nurses in Makassar. Participants in the study were 280 nurses working in six hospitals. The sampling technique used in this research is stratified random sampling. The data analysis performed was the univariate and bivariate analysis with Simple Linear Regression test. The results of this study indicate that self-efficacy contributes to $93 \%$ of work engagement in nurses in Makassar. In other words, the better self-efficacy in the nurse the higher the work engagement and vice versa.
\end{abstract}

\section{Keywords-self-efficacy component; work engagement; nurse}

\section{INTRODUCTION}

The success of an organization in achieving a goal cannot be separated from the role of employees. Employees are not only objects in the achievement of organizational goals but also become subjects or actors who become planners, executors and controllers who always play an active role in realizing organizational goals. Therefore, the functions and roles of employees are needed to maximize the performance, productivity, and effectiveness of the organization through efficient workings resulting in added value for the organization [1].

Based on these needs, the organization requires energetic and dedicated employees, i.e. employees who have work engagement in their work [2]. Schaufeli states that there are some jobs that require high work attachment, including nurses [3]. Nurses act as the front guard in performing health services where either good or poor health services can be assessed from the performance of nurses [4]. Thus, it can be said that nurses have a decisive role in improving the quality of health services.

Knowing the importance of the position and the role of nurses in the continuity of health services, it is natural that the health service institution is required to provide quality services in accordance with standards and reach all levels of society as well as require professional employees [5]. In fact, the performance and competence of nurses in hospitals is still low. This is evidenced from the results of research conducted by Nurhaeni [6] on the performance of nurses in various regions in Indonesia that indicate poor performance. In RS Jiwa Dadi Makassar, it was found that there was $57.8 \%$ poor performance and $42.2 \%$ good performance. Another study related to the quality of nursing services at the Regional General Hospital Power by Khumayrah [7] states that the attitude of nurses in providing services to patients seemed unprofessional with a low response rate and is still slow. Thus, the patient complains to the nurse for the service received.

Knowing the importance of the position and the role of nurses in the continuity of health services, it is natural that the health service institution is required to provide quality services in accordance with standards and reach all levels of society as well as require professional employees [5]. In fact, the performance and competence of nurses in hospitals is still low. This is evidenced from the results of research conducted by Nurhaeni [6] on the performance of nurses in various regions in Indonesia that indicate poor performance. In RS Jiwa Dadi Makassar, it was found that there was $57.8 \%$ poor performance and $42.2 \%$ good performance. Another study related to the quality of nursing services at the Regional General Hospital Power by Khumayrah [7] states that the attitude of nurses in providing services to patients seemed unprofessional with a low response rate and is still slow. Thus, the patient complains to the nurse for the service received.

One of the main causes of low nurse performance and competence in Indonesia is the demand for the workload received is greater than should be done. This is evidenced by the results of research from Hadju et al. [8] indicating that the factors that make the nurse working in RS Stella Maris Makassar experiencing job stress is a high work load of $53.3 \%$ experienced by nurses and $76.5 \%$ makes nurses severe stress, $63.3 \%$ due to heavy work routine and $88.2 \%$ make the nurses experience severe stress, as well as inadequate working environment atmosphere of $50 \%$ and $76.5 \%$ makes the nurses stressed. In addition, the results of a survey compiled by the National Nurses Association of Indonesia or PPNI in 2009 in Makassar also showed $51 \%$ of nurses experiencing work stress, dizziness, tiredness, less rest because the workload is too high. In essence, work engagement plays an important role for the nurse because in the health care environment, the handling of the patient depends on the worker who is in the hospital. Not only that, high work engagement can also help hospitals where nurses work to operate better by facilitating the achievement of hospital missions beyond other employees and has a direct 
impact on the image of good hospitals in the eyes of consumers/patient. Based on several studies on factors affecting work engagement, it was found that the psychological aspect of the individual is a factor that influences the appearance of work engagement on one self, one of which is self-efficacy. Self-efficacy defined as a belief in one's ability to take and give enough effort to succeed in doing challenging tasks [9].

Self-Efficacy in every employee has an important role. Individuals with strong self-efficacy will have stronger enthusiasm and perseverance in facing challenges. Conversely, individuals with weak self-efficacy will easily give up and break down when faced with difficulties and problems [10]. Self-efficacy builds the appearance of employee work engagement. In this case, if self-efficacy is built well in the employee it will build work attachment that directly affects the performance of one's work [11]. Self-efficacy in nurses will be low due to stressors. The stressors are high emotional demands in doing their work [12]. The stressors make the nurse burn out. The burnout experienced makes the nurse not confident in the work. The sense of self-confidence represents the feeling of incompetent employees and lack of achievement and productivity in work [13]. This problem, in turn, negatively impacts the contribution of nurses in doing their work because they cannot face the challenges in their work which also indirectly affect the quality of their work. Based on previous studies that have been done, there is a partial influence of selfefficacy to work engagement. This is reinforced by the theory that self-efficacy is one factor that has a positive correlation to improve work engagement $[11 ; 14 ; 15]$. If one looks at how the contribution of self-efficacy to work engagement in employees who have previously been described, the nurse becomes an important part in the way the hospital achieves organizational goals. Therefore, the researcher considers that there is a need to conduct research to know how far the contribution of selfefficacy to work engagement in nurses in Makassar City, considering the influence of self-efficacy and work engagement in work performance on the nurse.

\section{LITERATURE REVIEW}

\section{A. Work Engagement}

Kahn defines work engagement as an overview of employees who are physically, cognitively and emotionally connected to their work. Work Engagement refers to focused energy directed to organizational goals [16]. Work engagement is considered a meaningful motivational construct which means as a positive state it is associated with wellbeing in work, vigorousness, and strong attachment to his work [17]. Thus, the concept of work engagement relates to the extent to which individuals are able to be fully engaged in their work and motivated in achieving organizational goals.

The work-engagement aspects put forward by Schaufeli et al. are vigor (powerful energy and mental rush during work), dedication (strong feeling of being bonded to work) and absorption (full concentration and seriousness in doing the work). The characteristics of individuals who have high work engagement proposed by Federman is the focus in completing a job and also on the next job; feeling as part of a team and something bigger than themselves; feeling capable and does not feel pressure in making a leap in work; as well as working with change and approaching challenges with adult behavior [18].

Bakker \& Demerouti outlines that the various drivers of work engagement are personal resources such as self-efficacy, optimism, resilience and self-esteem; job resources such as autonomy, social support, opportunities to learn and grow as well as feedback on performance; as well as job demands related to the characteristics of the job such as time and pressure in work, work environment and work role. The three components of the incentive for the birth of work engagement are interdependent. When job demands and job resources are low it will erode the attachment of work and generate burnout in employees. Conversely, if job demands are low and job resources are high then employees will be motivated and tied to their work. Meanwhile personal resources positively support job resources and improve employee engagement.

\section{B. Self Efficacy}

Albert Bandura as the originator of the birth of the term self-efficacy provides its definition as the belief or the the confidence an individual has about their ability to steer motivation, cognitive abilities, as well as the actions necessary to perform tasks successfully in certain contexts [9]. Self efficacy is self-assessment, where it judges whether to take action is good or bad, right or wrong, can or cannot do. In other words, self-efficacy leads to individual self-confidence that determines how an individual feels, thinks and motivates himself to succeed in achieving success, based on a selfassessment of their ability to accomplish tasks and challenges.

Aspects of self-efficacy described by Bandura are magnitude (task difficulty level), generality (wide range of behavioral coverage) and strength (strength of confidence) [19]. Each individual has a different level self-efficacy; a high level of self-efficacy in the individual is influenced by many factors. Bandura identifies that self-efficacy is gained, can be developed and can also decrease.

Self-efficacy by Feist is derived from four sources: Performance Attainment, Vicarious Experience, Verbal Persuasion, and Physical and Emotional State [20]. These four sources will be selected and incorporated by the individual to form a perception of his or her ability, the self-efficacy of the individual is influenced by the perception of his or her ability. In this case, the high level of self-efficacy possessed by the individual depends heavily on the tasks faced by the individual. External factors outside the self-will indirectly affect the high/low self-efficacy of individuals; in this case, external factors in the form of rewards given to individuals and individual roles in the environment.

Individuals with high self-efficacy have the characteristic of having a high target for themselves and consciously choosing a difficult task; likes and develops themselves with challenges; have high personal motivation; gives effort to reach their goals; and when they encounter difficulties they will survive [9]. 


\section{METHOD}

\section{A. Operational Definition of Research Variables}

Work engagement is the employee's attachment to their work which is characterized by the presence of three components within them, namely vigor, dedication, and absorption. The results of work engagement measurements is obtained from the total score of constructs obtained from the filling of Utrecht Work Engagement Scale measuring instrument. The total score obtained is a score of the three components of work engagement. The total score obtained represents the higher the total score signifies the higher one's work engagement.

Self-efficacy is the employee's perception of his or her ability to perform and accomplish challenging tasks on his job. The self-efficacy measurement results are obtained from the total construct score of the self-efficacy measuring instrument, which is one of the components in psychology capital of the research participants. The total score obtained represents the higher the total score signifies the higher the self-efficacy of a person. Thus, the measuring tool used is a Self-Efficacy measuring tool that is a sub-scale of Psychological Capital Questionnaire (PCQ).

\section{B. Participants}

The population of this study is all nurses working in hospitals managed by the government of Makassar, amounting to as many as 1717 people, while the participants in this study are nurses who work on 6 hospitals run by the government of Makassar with a sample size of 280 people. The number of participants is taken from a number of populations by using the Slovin formula with error standard of 5\%. Sampling is done by stratified random sampling that randomly selected participants in each department in selected hospitals.

\section{Data Collection Technique}

Data collection techniques in this study used two measuring instruments. First, in measuring work engagement variables Utrecht Work Engagement Scale (UWES) was developed by Schaufeli et al [3]. This measuring tool is composed of the dimensions of work engagement namely vigor, dedication, and absorption. Second, the self-efficacy variable, measured using self-efficacy measuring instruments incorporated in Psychological Capital Questionnaire (PCQ), was developed by Luthans, Youssef, and Avolio [9] by combining four measuring instruments with 6 items to measure self-efficacy. This measure refers to the theory Data analysis technique used in this research is simple linear regression analysis. Scores obtained from each scale are transformed to logit values using the Winstep software application. In this case, the logit value used in analyzing the data is the logit value of the person in the person gauge table on the Rasch Model results. The transformation of the data is included in the Rasch model. Sumintono and Widhiarso stated that Rasch modeling is an analytical tool that can test the validity (validity) and reliability of research instruments, even testing the suitability of person and item simultaneously by accommodating probability approach in viewing attributes of a measuring object [21] proposed by Albert Bandura. The two measuring instrument used in this research has gone through the stages of validity and reliability test by analyzing the results of Pearson measure and item measure through the application of Winsteps software.

\section{Data Analysis}

Data analysis technique used in this research is simple linear regression analysis. Scores obtained from each scale are transformed to logit values using the Winstep software application. In this case, the logit value used in analyzing the data is the logit value of the person in the person gauge table on the Rasch Model results. The transformation of the data is included in the Rasch model. Sumintono and Widhiarso stated that Rasch modeling is an analytical tool that can test the validity (validity) and reliability of research instruments, even testing the suitability of person and item simultaneously by accommodating probability approach in viewing attributes of a measuring object [21].

\section{RESEARCH RESULT AND DISCUSSION}

\section{A. Research Result}

This study aims to determine the extent of self-efficacy's contribution to work engagement on nurses in Makassar City. The number of participants in this study amounted to as many as 280 nurses in six hospitals run by the government of Makassar. The data analysis technique used is simple linear regression analysis on self-efficacy variable as independent variable and work engagement as independent variable.

Based on the results of statistical analysis, the statistical test results obtained that the value of $R$ of 0.96 indicates a relationship between self-efficacy and work engagement, because it meets the $R>0.05$ rule. The contribution amount is shown on the $\mathrm{R}$ square value of 0.93 , which is formulated in percentage units, so that the contribution of self-efficacy to the work engagement on the nurse in Makassar City is $93 \%$ and $7 \%$ is influenced by other variables. In addition, the significance value obtained is 0.00 indicating that the value satisfies the sig $\mathrm{F}<0.05$ rule. Thus, it can be concluded that $\mathrm{H} 0$ is rejected and $\mathrm{Ha}$ is accepted in this research hypothesis. This means that there is a significant contribution between selfefficacy and work engagement on nurses in Makassar City. In other words, self-efficacy predicts the birth of work engagement in nurses. This shows that the better self-efficacy in the nurse, the higher the work engagement and vice versa, the lower the self-efficacy in the nurse, the work engagement will also be lower.

\section{B. Discussion}

The result of hypothesis testing shows that $\mathrm{Ha}$ is accepted by the amount of contribution of independent variable $\mathrm{R}$ square equal to 0,93 with significance level equal to $0,00(\mathrm{~F}<0,05)$ to the dependent variable. These results indicate that there is a significant contribution of self-efficacy to work engagement on nurses in Makassar City. In addition, the results obtained in this study also proves that one of the factors that influence in improving work engagement on nurses is self-efficacy, with a contribution amount of $93 \%$. 
The results reinforce the theory that if nurses have work engagement, so nurses will work according to their job demands, be more responsible, more involved, enjoy their work more, and show good work performance as well [2;11]. While the nurses who have self-efficacy will try to work optimally, as expected [19]. Thus, if both are present in the nurse then, the nurse will help the hospital where she works to operate better by facilitating the achievement of the mission of the hospital by providing good health services.

The results of this study also correspond to previous studies of Xanthopoulou, Bakker, Demerouti and Schaufeli; Yakin \& Erdil; Rigg, et al.,; Simbula \& Guglielmi; Allessandri, et al.,; Ouweneel, et al.,; and Bimantari which state that there is a positive contribution or influence from self-efficacy to work engagement. These studies mean that self-efficacy predicts the birth of an individual's work engagement in their work. It also illustrates that the higher level of self-efficacy that is owned by the nurse, the higher the work engagement on the nurse's self and vice versa, the lower the self-efficacy level of the nurse, the nurse's work engagement will also be lower.

In essence, creating the achievement of vision and mission of the hospital as expected by an organization, especially the hospital, can be realized with the presence of nurses that have a high level self-efficacy - they can accomplish the task given in accordance with the demands of their work in any condition and situation. When the nurse can complete the job well, then that's when work engagement rises in the nurse by feeling more responsible, more involved, and more enjoying their job.

This research cannot be separated from the limitations in the process, among other conditions and the situation of nurses who are busy with their work so as to enable the nurses' lack of concentration in doing the questionnaire. Thus, it took quite a long time to collect the questionnaire and some questionnaires were not used because of incomplete answers. In addition, there was a research bias due to the process of filling questionnaires in some hospitals was not witnessed directly by researchers due to demand for nurse division head, which resulted in some uniformity of answers in the same division in some hospitals.

\section{CONCLUSION AND SUGGESTIONS}

\section{A. Conclusion}

This study wanted to find how far self-efficacy contributes to work engagement on nurses in Makassar City. Based on the results of data analysis which have been done in this research, the main result of research can be concluded that there is positive contribution between self-efficacy and work engagement at nurse in Makassar City. This means that selfefficacy predicts the birth of work engagement in nurses. The higher level of self-efficacy that is owned by the nurse, the higher the work engagement on the nurse self and vice versa, the lower the self-efficacy level of the nurse, the nurse's work engagement will also be lower.

\section{B. Advice}

- Further research is expected to become a reference and can conduct a similar research by further and comprehensive examination on the overall components of psychological capital to work engagement, to prove that it is true that nurses who have high psychological capital level will have high work engagement. This further research is intended to be able to generalize the concept of psychological capital and work engagement, especially for nurses in Makassar City.

- Future research is expected to select a population/research participants not only from hospitals managed by the government alone. It can also use research participants from private hospitals with data acquisition that will be richer and more varied, allowing for more general outcomes.

- Further research is expected to further minimize or anticipate factors that can lead to research bias, such as the time of research, the time of the questionnaire, and others.

- To the Hospital Management, this research is expected to be a reference to hold socialization to bridge nurses in spurring self-building as well as improving self-efficacy and work engagement. Thus, it can create an optimal performance for both the nurses and for the achievement of the vision and mission of the organization, which in this case is the hospital.

\section{REFERENCES}

[1] Nawawi, H. Manajemen strategik organisasi non-profit bidang pemerintahan dengan ilustrasi di bidang pendidikan. Yogyakarta: Gadjah Mada University Press, 2000

[2] Bakker, A. B., \& Leither, M. P. A Handbook of Essential Theory and Research. USA: Psychology Press, 2010

[3] Schaufeli, W. B. (2011). "Work engagement: a key concept of a positive occupational health psychology?". [Online] Available: http://www.psihologietm.ro/OHPworkshop/schaufeli_work_engagement 1.pdf [June. 17, 2017]

[4] Gatot, D.B. \& Fruchter, B. (2005, June). "Hubungan karakteristik perawat, isi pekerjaan dan lingkungan pekerjaan terhadap kepuasan kerja perawat di instalasi rawat inap rsud gunung jati cirebon”. Makara Kesehatan. [Online]. 9. Pp. 1-8. Available: http://repository.ui.ac.id/dokumen/lihat/100.pdf. [June. 17, 2017]

[5] Utama, Surya.(2003). Memahami fenomena kepuasan pasien rumah sakit. [Online]. Available: HTTP://72.14.235.104/SEARCH?q=cache:pvwimpcs8fkj:library.usu.ac. id/download/fkm/fkmsurya1.pdf=karakteristik+palayanan+keperawatan \&hl=id\&ct=clnk\&cd=38\&gl=id. [June. 17, 2017].

[6] Nurhaeni. "Faktor-faktor determinan yang berhubungan dengan kinerja perawat pelaksana di rs jiwa makassar." M.S. thesis, University of Indonesia, Jakarta, 2001.

[7] Khumayrah, Ummi. "Kualitas pelayanan rumah sakit umum daerah daya makassar.” Bachelor thesis, Hasanuddin University, Makassar, 2015

[8] Siringoringi, E., Nontji, W., \& Hadju, V. "Faktor-faktor yang berhubungan dengan stres kerja perawat di ruang icu rs stella maris makkasar." M.S. thesis, Hasanuddin University, Makassar, 2010

[9] Luthans, F., Youssef, C. M., \& Avolio, B. J. Psychological Capital: developing the human competitive edge. New York: Oxford University Press, 2007.

[10] Hermanto, J. "Hubungan antara efikasi diri dan stress kerja terhadap intensi pindah kerja”. M.S. thesis, Gajah Mada University, Yogyakarta, 2004.

[11] Xanthopoulo, D., Bakker, A. B., Demerouti, E., \& Schaufeli, W. B. "Work engagement and financial returns: A diary study on the role of job and personal resources". Journal of occuopational and organizational psychology, vol. 88, pp. 183-200, 2009. 
[12] Poulsen, M. G., Poulsen, A. A., Khan, A., Poulsen, E. E., \& Khan, S. R. "Work engagement in cancer workers in queensland: The flip side of burnout". Journal of medical imaging and radiation oncology, vol. 55, pp. 425-432, 2011.

[13] Maslach, C., \& Leiter, M. P. "Early predictors of job burnout and engagement". Journal of applied Psychology, vol. 93, pp. 498-512, 2008.

[14] Heuven, E., Bakker, A. B., Schaufeli, W. B., \& Huisman, N. "The role of self efficacy in performing emotion work". Journal of Vocational Behavior, vol. 69, pp. 222-235, 2006.

[15] Breso, E., Schaufeli, W. B., \& Salanova, M. "Can a self-efficacy-based interbention decrease burnout, increase engagement, and enhance performance? A quasi-experimental study". High Education, vol. 61, pp. 339-355, 2011.

[16] Macey, Schneider. "The meaning of employee engagement". Journal of Industrial and Organizational Psychology, vol. 1, pp. 3-30, 2008.
[17] Bakker, A.B., Schaufeli, W. B., \& Taris, T. W. “dr Jekyll or Mr Hyde? On the Differences between work engagement and workholism," in Research Companion to Working Time and Work Addiction, RJ. Burke (ed). Cheltenham, Uk and Northampton, MA, USA: Edward Elgar. 2006.

[18] Federman, B. Employee engagement: A roadmap for creating profits, optimizing performance, and increasing loyalty. San Fransisco: Jossey Bass, 2009.

[19] Bandura, A. Self-Efficacy: The Exercise of Control New York. W.H. Freeman and Company, 1997.

[20] Feist, J. \& Feist, G.J. Theories of Personality. Singapore: The McGrowHill, 2009.

[21] Sumintono, B., \& Widhiarso, W. Aplikasi Pemodelan Rasch pada Assessment Pendidikan. Cimahi: Trim Komunikata, 2015. 